\section{Efektivitas Ekstrak Pektin dari Kulit Buah Jeruk Bali (Citrus maxima) Sebagai Antimikroba}

\author{
Nur Wana \\ Halifah Pagarra
}

\begin{abstract}
Abstrak. Tujuan dari penelitian ini adalah untuk menyelidiki efektivitas ekstrak pektin dan aktivitas antimikroba ekstrak pektin dari kulit jeruk bali (Citrus maxima) dengan variasi $\mathrm{pH}$, suhu, dan waktu ekstraksi. Penelitian ini adalah penelitian eksperimental dengan pengujian laboratorium menggunakan Rancangan Acak Lengkap (RAL) dengan pengulangan tiga kali faktorial 2x3x3. Fdaktor A adalah pH: 1,5 (A1), 2,5 (A2). Faktor B adalah suhu pemanasan: $60^{\circ} \mathrm{C}$ (B1), $80^{\circ} \mathrm{C}$ (B2), 100oC (B3). Faktor C adalah waktu: 60 menit (C1), 90 menit (C2), 120 menit (C3). Sedangkan pengukuran desain aktivitas antimikroba dilakukan dengan menghitung diameter zona hambat $(\mathrm{mm})$. Semua data yang diperoleh dianalisis menggunakan ANOVA $(\alpha=0,05 \%$, kemudian dilanjutkan dengan uji lanjutan Tuckey menggunakan SPSS). Ekstraksi pektin dari kulit grapefruit menggunakan metode konvensional dengan asam klorida $(0,5 \mathrm{~N} \mathrm{HCl})$. Proses ekstraksi dilakukan dengan memanaskan hot plate dengan memvariasikan suhu (60 oC; $80 \mathrm{oC} ; 100 \mathrm{oC}), \mathrm{pH}(1,5 ; 2,5)$, dan waktu ekstraksi $(60 ; 90 ; 120$ menit). Hasil pektin yang signifikan diperoleh diuji aktivitas antimikroba dan diukur zona penghambatan yang dihasilkan berdasarkan diameter area antimikroba. Hasil penelitian menunjukkan bahwa ekstraksi dipengaruhi oleh $\mathrm{pH}$, suhu, dan waktu ekstraksi dan hasil pektin tertinggi diperoleh dengan ekstraksi dengan ph 2.5 , suhu $60 \mathrm{oC}$, waktu 90 menit sebanyak 27,8\%. Sedangkan aktivitas antimikroba ekstrak pektin dari kulit jeruk bali (Citrus maxima) memiliki aktivitas antibakteri karena dapat menghambat pertumbuhan bakteri Escherichia coli, Staphylococcus aureus. Namun, ia tidak memiliki aktivitas antijamur terhadap Candida albicans.

Kata kunci: Kulit jeruk bali (Citrus axima), Pectin, ekstraksi, aktivitas antimikroba.
\end{abstract}

\section{Pendahuluan}

Jeruk bali (Citrus maxima) merupakan jenis tanaman dengan ukuran buah yang lebih besar dibandingkan jeruk yang biasa kita temui di pasar. Tanaman ini tersebar di Sumatera, Jawa, Bali, Kalimantan, dan Sulawesi. Di Sulawesi sendiri jeruk bali banyak terdapat di Desa Padang Lampe, Kecamatan Marang, Kabupaten Pangkep. Produksi jeruk bali diberbagai daerah di Indonesia mencapai $511 \mathrm{~kg} /$ ton pertahunnya, dari produksi tersebut dihasilkan limbah kulit buah jeruk bali sebesar $208 \mathrm{~kg} /$ ton. Jeruk bali mengandung banyak komponen nutrisi yang terkandung didalamnya. Sebagian besar komponen jeruk bali terletak pada kulitnya, diantaranya terdapat senyawa alkaloid, flavonoid, likopen, vitamin C, serta yang paling dominan adalah pektin dan tannin (Rahmawati dan Putri, 2013). Jeruk bali (Citrus maxima) dapat dikonsumsi dalam bentuk buah segar ataupun hasil olahan. Produk olahan adalah produk primer. Disamping produk primer masih tersimpan potensi yang besar yaitu produk sekunder seperti limbah

\section{BIONATURE}

\author{
p-ISSN 1411 - 4720 \\ e-ISSN 2654 - 5160
}

Abstract. The aim of this study was to investigate the effectiveness of pectin extract and antimicrobial activity of pectin extract from the skin of grapefruit (Citrus maxima) with variations in $p H$

temperature, and extraction time. This study was an experimental study with laboratory testing using a completely randomized design (CRD) with $2 \times 3 \times 3$ factorial three times repetition. Factor $A$ is pH: 1.5 (A1), 2.5 (A2). Factor $B$ is the heating temperature: $60^{\circ} \mathrm{C}(\mathrm{B} 1), 80^{\circ} \mathrm{C}(\mathrm{B} 2)$, $100^{\circ} \mathrm{C}$ (B3). Factor $C$ is time: 60 minutes (C1), 90 minutes (C2), 120 minutes (C3). While the design measurement of antimicrobial activity is carried out by calculating the diameter of the inhibition zone $(\mathrm{mm})$. All data obtained were analyzed using ANOVA ( $\alpha=0.05 \%$, then continued by Tuckey's advanced test using SPSS). Extraction of pectin from the skin of grapefruit using a conventional method with hydrochloric acid $(0.5 \mathrm{~N} \mathrm{HCl})$. The extraction process was carried out by

heating the hot plate by varying the temperature ( $60 \mathrm{oC} ; 80 \mathrm{oC} ; 100 \mathrm{oC}), \mathrm{pH}$ $(1.5 ; 2.5)$, and extraction time $(60 ; 90 ; 120$ minutes). Significant pectin yields obtained were tested for antimicrobial activity and measured inhibitory zones produced based on the diameter of the antimicrobial area.

The results showed that extraction was influenced by $\mathrm{pH}$, temperature, and extraction time and the highest pectin yield was obtained by extraction with $p h$ 2.5 , temperature $60 \mathrm{oC}$, time 90 minutes as much as $27.8 \%$. While the antimicrobial activity of pectin extract from the skin of grapefruit (Citrus maxima) has antibacterial activity because it can inhibit the growth of Escherichia coli bacteria, Staphylococcus aureus. However, it has no antifungal activity against Candida albicans.

Keywords: Grapefruit skin (Citrus axima), Pectin, extraction, antimicrobial activity.

Nur Wana

Universitas Negeri Makassar Indonesia

Halifah Pagarra

Universitas Negeri Makassar Indonesia 
kulit buah jeruk bali. Limbah dari kulit buah jeruk bali masih kurang dimanfaatkan oleh masyaraka, padahal kulit buah jeruk bali memiliki banyak manfaat. Menurut Kristiyani (2013) salah satu manfaat kulit jeruk bali adalah untuk membuat pektin.

Pektin adalah substansi alami yang terdapat pada sebagian besar tanaman pangan. Beberapa jenis buah secara alami memiliki kandungan pektin yang cukup tinggi. salah satu buah yang memiliki kandungan pektin yang tinggi adalah jeruk bali (Citrus maxima). Tiap tahun kebutuhan pektin mengalami kenaikan sebesar 10-15\%. Di Indonesia, belum ada pabrik yang dapat mengolah pektin. Oleh karena itu Indonesia masih mengimpor pektin dari luar negeri. Sedangkan kebutuhan pektin di Indonesia semakin meningkat. Hal ini terbukti dengan semakin meningkatnya nilai impor (Sulihono, 2012).

Pektin merupakan senyawa polisakarida dengan bobot molekul tinggi, pektin digunakan sebagai pembentuk gel dan pengental dalam pembuatan jelly, marmalade, makanan rendah kalori dan dalam bidang farmasi digunakan sebagai antimikroba (Perina dkk, 2013).

Antimikroba (AM) adalah obat pembasmi mikroba, khususnya mikroba yang bersifat merugikan manusia (mikroba patogen). Escherichia coli, Staphylococcus aureus, dan candida albicans merupakan mikroba patogen (Ganiswara, 1995). Berbagai penelitian menyatakan bahwa tanaman jeruk memiliki aktivitas antibakteri terhadap E. coli dan S. aureus. Berdasarkan penelitiaan Sari (2015), ekstrak pektin dari kulit buah jeruk memiliki aktivitas antimikroba terhadap Staphylococcus aureus, Saccharomyces cerevisiae, Bacillus subtilis, Escherichia coli.

Oleh karena itu penulis tertarik untuk mengekstrak pektin dari kulit buah jeruk bali sebagai antimikroba untuk menghambat mikroba pathogen, setidaknya dengan memanfaatkan kulit buah jeruk bali sebagai bahan baku pembuatan pektin dapat mengurangi impor pektin, sekaligus memanfaatkan kulit jeruk bali yang kurang populer di kalangan masyarakat menjadi sesuatu yang bernilai ekonomis lebih tinggi.

\section{Metode Penelitian}

Penelitian ini merupakan penelitian eksperimental yang dlakukan pada bulan Agustus sam pai Desember 2018. Penelitian dilakukan di Laboratorium Jurusan Biologi FMIPA UNM. Variabel bebas dalam penelitian ini adalah variasi $\mathrm{pH}$, suhu, dan waktu, sedangkan variabel terikat adalah pektin.

\section{Alat dan Bahan}

Alat yang digunakan yaitu, erlenmeyer $(250 \mathrm{ml}, 500 \mathrm{ml}$, dan $1000 \mathrm{ml})$, gelas kimia $(250 \mathrm{ml}$, $500 \mathrm{ml}$, dan $1000 \mathrm{ml})$, gelas ukur $(50 \mathrm{ml}, 500 \mathrm{ml}$, dan $1000 \mathrm{ml})$, pipet tetes, pipet ukur, batang pengaduk, corong, oven, autoclave, blender, cawan petri, termometer, $\mathrm{pH}$ meter, neraca analitik, saringan, ayakan, stopwatch, pisau, wadah, ose, tabung reaksi, rak tabung, mikropipet dan tip, spoit, botol pengencer, bunsen, laminar air flow (LAF), waterbath, hotplate, dan peralatan umum yang digunakan di laboratorium mikrobiologi.

Bahan yang digunakan yaitu kulit buah jeruk bali (Citrus maxima), aluminium foil, plastik, label, karet, wrap, etanol $96 \%$, etanol 70\%, aquades, $\mathrm{HCl}$ 0,5 N, $\mathrm{HCl}$ pekat, $\mathrm{FeCl}$, R.Wagner, Magnesium, $\mathrm{NaOH}$ 0,5 N, nystatin, tetrasiklin, medium NA (Nutrient Agar), medium PDA (Potato Dextrose Agar), isolat bakteri Eschericia coli, Candida albicans dan Staphylococcus aureus, 
Efektivitas Ekstrak Pektin dari Kulit Buah Jeruk Bali (Citrus maxima) Sebagai Antimikroba

(hlm. 140-151)

e-ISSN 2654-5160 p-ISSN 1411-4720

\section{Prosedur Penelitian}

\section{Tahap Ekstraksi Pektin}

a. Ekstraksi pektin

Kulit buah jeruk bali yang sudah kering di haluskan dengan menggunakan belender dan ditimbang sebanyak 5 gram. Kemudian penambahan aquades sebanyak $100 \mathrm{ml}$, dan ditambahkan pelarut asam klorida $(\mathrm{HCl}) 0,5 \mathrm{~N}$, sampai $\mathrm{pH}$ larutan yang sudah ditentukan $(1.5$ dan 2,5$)$. Selanjutnya dipanaskan sambil diaduk pada suhu yang ditentukan $\left(60^{\circ} \mathrm{C}, 80^{\circ} \mathrm{C}, 100^{\circ} \mathrm{C}\right)$ selama waktu yang ditetapkan (60, 90, 120 menit). Campuran yang telah diekstrak disaring dengan menggunakan saringan dan diperas untuk memisahkan filtrat dari ampasnya.

\section{b. Pengendapan}

Filtrat didinginkan sampai dengan suhu kamar kemudian dilakukan pengendapan pektin dengan menambahkan etanol 96\%. Perbandingan filtrat dengan etanol yang ditambahkan adalah 1:1. Proses pengendapan dilakukan selama 24 jam.

\section{c. Pencucian}

Endapan pektin yang diperoleh dicuci dengan menggunakan etanol 96\% untuk menghilangkan sisa asam. Pemisahan endapan pektin dengan etanol bekas cucian dilakukan dengan menggunakan spoid (tanda tidak lagi bereaksi dengan asam adalah ketika air bekas cucian pektin berwarna merah bila ditetesi phenolftalein).

\section{d. Pengeringan}

Pengeringan pektin basah hasil cucian dilakukan dalam oven pada suhu $50^{\circ} \mathrm{C}$ selama 3 hari. Tepung pektin diperoleh dengan memblender pektin kering kemudian dilakukan pengayakan. Rendemen pektin tertinggi atau signifikan yang didapat dari hasil ekstraksi pektin kulit buah jeruk bali akan dilakukan uji aktivitas antimikroba dengan konsentrasi 0,5\%, 0,75\%, dan $1 \%$.

\section{Tahap Analisis Fitokimia}

Analisis kandungan senyawa aktif dilakukan berdasarkan metode Sari (2015). Analisis kandungan senyawa aktif dilakukan beberapa yaitu, uji alkaloid, uji tanin, uji saponin, uji flavonoid.

\section{Tahap Uji Aktivitas Antimikroba}

Pengujian aktivitas antimikroba

dari pektin kulit buah jeruk bali (Citrus maxima) dilakukan dengan mengamati zona hambat menggunakan metode paper disk. Setiap cawan petri berisi 1 sampel dengan 3 konsentrasi berbeda $(0,5 \%, 0,75 \%, 1 \%)$ serta kontrol positif dan kontrol negatif.

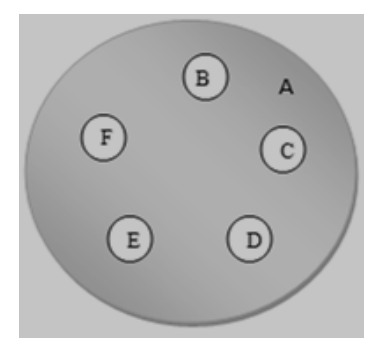

\section{Gambar 1. Skema Penempatan Paper Disk Pada Cawan Petri.}

Ket: A: Medium yang telah diinokulasi mikroba; B, C, dan D: Ekstrak 0,5\%, 0,75\%, dan 1\%; E: Kontrol negatif; F: Kontrol positif.

Sampel yang digunakan yaitu ekstrak pektin dari kulit buah jeruk bali dengan konsentrasi $(0,5 \%, 0,75 \%, 1 \%)$, langkah pertama yang harus dilakukan adalah mensterilkan kedua tangan dengan menyemprotkan alkohol 70\%. Menyiapkan 3 cawan petri setiap mikroba uji dan diberi label untuk masing-masing konsentrasi ekstrak, kontrol positif, dan kontrol negatif. Kemudian tepi cawan petri dipanaskan dan medium NA maupun PDA dituang kedalam cawan petri sebanyak 15-20 ml, dan ditunggu hingga memadat. Sambil menuggu medium memadat setiap 
paperdisk ditetesi larutan uji sebanyak $20 \mu$ l, yaitu pektin dengan konsetrasi 0,5\%, 0,75\%, 1\%, nystatin, dan tetrasiklin, kontrol positif $(+)$, Aquades kontrol negatif $(-)$ hingga paperdisk jenuh.

Medium NA dan PDA yang telah padat, permukaanya diinokulasikan dengan bakteri $(E$. coli, S. aureus) dan jamur (c. albicans) dengan metode gores sinambung secara padat. Selanjutnya masing-masing paperdisk yang telah ditetesi larutan uji diletakkan diatas medium, dimana masing-masing medium berisi 5 paperdisk. Kemudian diinkubasi selama 2 hari untuk bakter (E. coli, S. aureus) dan 3 hari untuk jamur (c. albicans), dan diukur zona hambat dengan menggunakan jangka sorong.

\section{Analisis data}

Pengolahan data dilakukan dengan Rancangan Acak Lengkap (RAL) pola faktorial 2x3x3 sebanyak tiga kali ulangan. Faktor A adalah pH: 1,5 (A1), 2,5 (A2). Faktor B adalah suhu pemanasan: $60{ }^{\circ} \mathrm{C}(\mathrm{B} 1), 80{ }^{\circ} \mathrm{C}(\mathrm{B} 2), 100{ }^{\circ} \mathrm{C}$ (B3). Faktor $\mathrm{C}$ adalah waktu 60 menit (C1), 90 menit (C2), dan 120 menit (C3) data yang diperoleh dianalisis menggunakan ANOVA. Sedangkan rancangan pengukuran aktivitas antimikroba dilakukan dengan menghitung diameter zona hambat $(\mathrm{mm})$. Semua data yang diperoleh dianalisis menggunakan ANOVA ( $\alpha=0.05 \%)$ kemudian dilanjutkan dengan uji lanjut Tuckey menggunakan program SPSS (Statistical Package for Social Science

\section{Hasil dan Pembahasan}

\section{Hasil Penelitian}

\section{Hasil Ekstrak Pektin dari Kulit Buah Jeruk Bali (Citrus maxima)}

Ekstraksi pektin dari kulit buah jeruk bali (Citrus maxima) menggunakan metode konvensional atau metode pemanasan dengan pelarut asam klorida $(\mathrm{HCl} 0,5 \mathrm{~N})$. Proses ekstraksi dilakukan dengan pemanasan diatas hot plate dengan variasi $\mathrm{pH}(1,5$ dan 2,5), suhu $\left(60^{\circ} \mathrm{C}, 80^{\circ} \mathrm{C}, 100^{\circ} \mathrm{C}\right)$ dan waktu ekstraksi $(60,90,120$ menit). Hasil rendemen pektin dapat dilihat pada Tabel 1.

\section{Tabel 1. Hasil Rendemen Pektin Dari Kulit Buah Jeruk Bali (Citrus maxima)} Terhadap pH, Suhu, Dan Waktu Yang Berbeda.

\begin{tabular}{|c|c|c|c|}
\hline Faktor 1 & Faktor 2 & Faktor 3 & \multirow{2}{*}{ Rata-Rata Rendemen Pektin (\%) } \\
\hline pH & Suhu $\left({ }^{\circ} \mathrm{C}\right)$ & Waktu (menit) & \\
\hline \multirow[t]{9}{*}{1,5} & 60 & 60 & 10 \\
\hline & & 90 & 18,46 \\
\hline & & 120 & 17,40 \\
\hline & 80 & 60 & 13,67 \\
\hline & & 90 & 10,93 \\
\hline & & 120 & 11,13 \\
\hline & 100 & 60 & 9,20 \\
\hline & & 90 & 11 \\
\hline & & 120 & 14,46 \\
\hline \multirow[t]{9}{*}{2,5} & 60 & 60 & 10,13 \\
\hline & & 90 & 23,06 \\
\hline & & 120 & 10,13 \\
\hline & 80 & 60 & 11,13 \\
\hline & & 90 & 10,80 \\
\hline & & 120 & 10,06 \\
\hline & 100 & 60 & 14,40 \\
\hline & & 90 & 15,33 \\
\hline & & 120 & 12,93 \\
\hline
\end{tabular}


Ekstrak pektin yang diperoleh kemudian ditentukan rendemen pektin, rendemen pektin diperoleh dari total pektin yang dihasilkan dibagi bubuk kulit jeruk yang digunakan dikali $100 \%$. Hasil rendemen pektin dari 54 sampel didapatkan rendemen pektin yang berbeda-beda pada setiap perlakuan, karna dipengaruhi oleh faktor $\mathrm{pH}$, suhu, dan waktu. Hasil rendemen pektin tertinggi diperoleh pada ekstraksi dengan $\mathrm{pH} 2,5$, suhu $60^{\circ} \mathrm{C}$, waktu 90 menit sebesar $23,06 \%$. Rendemen pektin terendah diperoleh pada ekstraksi dengan $\mathrm{pH} 1,5$, suhu $100{ }^{\circ} \mathrm{C}$, waktu 60 menit sebesar $9,20 \%$.

\section{Hasil Uji Fitokimia}

Fitokimia adalah bahan kimia tumbuhan non-nutritif yang memiliki berbagai tingkat sifat pencegahan penyakit. Senyawa kimia metabolit sekunder merupakan sumber bahan baku yang tak ternilai untuk obat tradisional (Sirait, M. 2007). Pengujian fitokimia dilakukan untuk mengetahui kandungan senyawa kimia metabolit sekunder yang terdapat didalam ekstrak pektin dari kulit buah jeruk bali (Citrus maxima), sehingga dapat diketahui metabolit sekunder yang berpotensi memiliki efek terhadap aktivitas antimikroba. Hasil pengujian fitokimia dapat dilihat pada Tabel 2.

\section{Tabel 2. Hasil Pengujian Fitokimia Ekstrak Pektin Dari Kulit Buah Jeruk Bali}

\begin{tabular}{|c|c|c|}
\hline Senyawa Aktif & Warna & Hasil \\
\hline Alkaloid & Kuning kecoklatan, tidak terdapat endapan & - \\
\hline Saponin & Kuning, terbentuk busa (berbuih) & + \\
\hline Flavonoid & Jingga, terbentuk busa (berbuih) & ++ \\
\hline Tanin & Hitam pekat & + \\
\hline
\end{tabular}

$\begin{array}{ll}\text { Keterangan: } & \\ \text { Tanda }(-) & =\text { Tidak terkandung senyawa } / \text { tidak terbentuk endapan; } \\ \text { Tanda }(+) & =\text { Terkandung senyawa } \\ \text { Tanda }(++) & =\text { Terkandung banyak senyawa; } \\ \text { Tanda }(++) & =\text { Terkandung lebih banyak senyawa; }\end{array}$

Hasil pengujian fitokimia menunjukkan bahwa adanya golongan senyawa metabolit sekunder yang terkandung dalam ekstrak pektin dari kulit buah jeruk bali (Citrus maxima), seperti, flavonoid, saponin, dan tannin. Pada pengujian alkaloid, hasil dinyatakan negatif karena tidak terbentuk endapan yang berarti tidak terdapat senyawa alkaloid dalam ekstrak pektin dari kulit buah jeruk bali (Citrus maxima). Untuk pengujian senyawa flavonoid, saponin, dan tannin menunjukkan hasil positif.

Pada pengujian flavonoid menunjukkan terjadinya perubahan warna jingga yang menandakan bahwa pektin terkandung banyak senyawa flavonoid. Pengujian saponin, terbentuk Sedikit busa yang menandakan bahwa pektin terkandung senyawa saponin. Untuk pengujian tanin terbentuk warna hitam pekat yang menandakan bahwa dalam ekstrak pektin dari kulit buah jeruk bali (Citrus maxima) terkandung lebih banyak senyawa tanin.

\section{Hasil Aktivitas Antimikroba}

Pengujian aktivitas antimikroba ekstrak pektin dari kulit buah jeruk bali (Citrus maxima) dilakukan dengan menggunakan pelarut aquades, dan membuat larutan induk. Pembuatan larutan induk ekstrak pektin dari kulit buah jeruk bali dilakukan dengan menimbang 5 gram ekstrak pektin kedalam $100 \mathrm{ml}$ aquades. Membuat konsentrasi 0,5 \%, 0,75\%, dan 1\% dibagi berdasarkan rumus pengenceran. Pengujian ini menggunakan metode difusi paper disc (kertas 
cakram) dengan ukuran kertas cakram $6 \mathrm{~mm}$, yang dapat diamati dengan melihat diameter zona hambat yang terbentuk di sekitar kertas cakram dan diukur menggunakanJangka sorong. Mikroba uji yang digunakan yaitu bakteri gram positif (Staphylococcus aureus), bakteri gram negatif (Escherichia coli), dan jamur (Candida albicans).

Kontrol positif yang digunakan sebagai pembanding yaitu untuk bakteri adalah tetrasiklin sedangkan untuk jamur menggunakan nystatin dan untuk kontrol negatif menggunakan aquades steril. Pengujian aktivitas antimikroba dilakukan 3 kali ulangan. Hasil Rata-rata diameter zona hambat ekstrak pektin dari kulit buah jeruk bali (Citrus maxima) pada akivitas antmikroba dapat dilihat pada Tabel 3. (Hasil olah data dapat dilihat di Lampiran 4).

Tabel 3. Rata - rata Diameter Zona Hambat Ekstrak Pektin dari Kulit Buah Jeruk Bali (Citrus maxima) pada Akivitas Antmikroba.

\begin{tabular}{|c|c|c|c|}
\hline \multirow{2}{*}{ Perlakuan } & \multicolumn{3}{|c|}{ Rata-Rata Diameter Zona Hambat (mm) } \\
\cline { 2 - 4 } & Escherichia coli & Staphylococcus aureus & Candida albicans \\
\hline EP ( 0,5\%) & $9,0000^{\mathrm{a}}$ & $7,6666^{\mathrm{ab}}$ & $6,0000^{\mathrm{a}}$ \\
\hline EP (0,75\%) & $9,3333^{\mathrm{b}}$ & $9,6666^{\mathrm{b}}$ & $6,0000^{\mathrm{a}}$ \\
\hline EP (1\%) & $10,3333^{\mathrm{b}}$ & $16,0000^{\mathrm{c}}$ & $15,0000^{\mathrm{a}}$ \\
\hline KP & $6666^{\mathrm{c}}$ & $21,0000^{\mathrm{b}}$ \\
\hline KN & $6,0000^{\mathrm{a}}$ & $6,0000^{\mathrm{a}}$ & $15,0000^{\mathrm{b}}$ \\
\hline
\end{tabular}

Keterangan: EP: Ekstrak Pektin; KP: Kontrol Positif; KN: Kontrol Negatif. Huruf yang sama dalam satu kolom menunjukkan "tidak berbeda nyata". Huruf yang berbeda dalam satu kolom menunjukkan "berbeda nyata". Huruf yang berbeda antar kolom menunjukkan" sangat berbeda nyata". Berdasarkan uji Tuckey dengan taraf kepercayaan $\alpha:$ 0,05.

Hasil pengujian aktivitas antimikroba menunjukkan, ekstrak pektin dari kulit buah jeruk bali (Citrus maxima) memiliki aktivitas antibakteri dengan adanya peningkatan konsentrasi larutan ekstrak uji, namun tidak menunjukkan adanya aktivitas antijamur dengan tidak terbentuknya zona hambat disekitar paper diks.

Bakteri Escherichia coli, dapat dilihat bahwa kontrol negatif tidak berbeda nyata terhadap ekstrak pektin $0,5 \%$, berbeda nyata terhadap ekstrak pektin $0,75 \%$, dan sangat berbeda nyata terhadap ekstrak pektin 1\% dan kontrol positif. Sedangkan terhadap bakteri Staphylococcus aureus menunjukkan bahwa kontrol negatif tidak berbeda nyata terhadap ekstrak pektin $0,5 \%$, dan sangat berbeda nyata terhadap ekstrak pektin $0,75 \%, 1 \%$, dan kontrolpositif.

Hasil pengujian aktivitas antijamur dari ekstak pektin kulit buah jeruk bali terhadap Candida albicans dapat dilihat bahwa kontrol negatif, ekstrak pektin 0,5\%, 0,75\%, dan 1\% tidak menunjukkan adanya aktivitas antijamur dengan tidak bertambahnya ukuran diamater dari kertas cakram sehingga hasil yang diperoleh tidak berbeda nyata. Hasil yang sangat berbeda nyata hanya diperoleh dari kontrol positif.

\section{Pembahasan}

\section{Ekstrak Pektin dari Kulit Buah Jeruk Bali (Citrus maxima)}

Sampel yang digunakan dalam penelitian ini adalah kulit buah jeruk bali (Citrus maxima). Kulit buah jeruk bali yang digunakan adalah kulit yang belum terlalu matang atau berwarna hijau kekuning kuningan dan belum ada tanda kebusukan, karna kulit yang belum terlalu matang mengandung pektin cukup tinggi dibandingan kulit buah jeruk bali yang sudah matang (Cahyanto, 2017).

Ekstarksi pektin dilakukan menggunakan metode konvensional atau metode pemanasan dengan pelarut asam klorida ( $\mathrm{HCl} \mathrm{0,5} \mathrm{N)}$. Proses ekstraksi dilakukan dengan pemanasan diatas 
hot plate dengan variasi $\mathrm{pH}(1,5$ dan 2,5$)$, suhu $\left(60^{\circ} \mathrm{C}, 80^{\circ} \mathrm{C}, 100^{\circ} \mathrm{C}\right)$ dan waktu ekstraksi $(60,90$, 120 menit) dengan tujuan untuk mendapatkan pektin yang signifikan. Menurut Sulihono (2012), prinsip dasar ekstraksi pektin adalah pektin dalam jaringan tanaman sebagai protopektin yang tidak larut dalam air (insoluble), dilakukan hidrolisis protopektin dalam air yang diasamkan dan dipanaskan untuk mengubah protopektin menjadi pektin yang bersifat larut dalam air. Dari hasil penelitian yang dilakukan dengan jumlah perlakuan sebanyak 54 sampel, didapatkan rendemen pektin yang berbeda-beda pada setiap perlakuan yang diberikan. Pektin yang dihasilkan dengan perlakuan yang berbeda akan menghasilkan berat yang berbeda pula, ini membuktikan bahwa Faktor $\mathrm{pH}$, suhu, dan waktu berpengaruh terhadap rendemen pektin yang dihasilkan. Hasil rendemen pektin tertinggi diperoleh pada ekstraksi dengan $\mathrm{pH}$ 2,5 , suhu $60^{\circ} \mathrm{C}$, waktu 90 menit sebesar $27,8 \%$.

Berdasarkan hasil diatas pengontrolan $\mathrm{pH}$ dalam ekstraksi pektin memiliki peranan penting karena dapat mempengaruhi rendemen pektin. Rentang $\mathrm{pH}$ untuk ekstraksi pektin bervariasi tergantung kepada bahan yang akan diekstraksi. Umumnya ekstraksi pektin dari kulit jeruk dilakukan pada pH 1,5 - 3 (Towle dan Christensen, 1973). Hal ini sesuai dengan penelitian yang dilakukan Prasetyowati (2009), menunjukkan bahwa pada pH 2,5 jumlah pektin yang diperoleh lebih banyak dibandingkan $\mathrm{pH}$ 1,5, dimana $\mathrm{pH}$ yang terlalu rendah atau terlalu asam dapat merusak pektin sehingga rendemen yang dihasilkan sedikit.

Jadi semakin rendah pH yang digunakan maka semakin sedikit pektin yang dihasilkan. Sedangkan $\mathrm{pH}$ diatas 3 yang kurang asam lebih sedikit ion hidrogen sehingga kalsium dan magnesium yang disubtitusi lebih sedikit. pH 2,5 memiliki banyak kalsium dan magnesium yang tersubtitusi sehingga jumlah pektin yang didapat makin banyak.

Suhu yang tinggi selama ekstraksi dapat meningkatkan rendemen pektin. Batas suhu ditentukan untuk mencegah kerusakan pada bahan. Secara umum, suhu ekstraksi untuk pektin adalah $60-90^{\circ} \mathrm{C}$. Sedangkan Waktu ekstraksi, Semakin lama waktu yang dibutuhkan untuk ekstraksi dalam pelarut, perolehan (yield) yang diperoleh semakin tinggi. Tetapi, penambahan waktu ekstraksi tidak sebanding dengan yield yang diperoleh (Herdigenarosa, 2013).

Hal ini sesuai dengan penelitian yang dilakukan Wang (2014), menunjukkan bahwa pada suhu $60^{\circ} \mathrm{C}$ dan waktu 90 menit memberikan rendemen pektin tinggi. Penggunaan suhu yang terlalu tinggi untuk kulit jeruk juga dapat mengakibatkan degradasi pektin dan waktu ekstraksi dilakuan pada waktu optimum, ekstraksi dilakukan selama pelarut yang digunakan belum jenuh. Pelarut yang telah jenuh tidak dapat mengekstraksi lagi atau kurang baik kemampuan untuk mengekstraksinya karena gaya pendorong (driving force) semakin lama semakin kecil. Akibatnya waktu ekstraksi semakin lama dan yield yang dihasilkan tidak bertambah lagi secara signifikan.

\section{Fitokimia}

Uji fitokimia bertujuan untuk mengetahui golongan senyawa metabolit sekunder yang terkandung dalam ekstrak pektin dari kulit buah jeruk bali (Citrus maxima). Menurut Septiani (2017) menunjukkan bahwa pektin dari kulit buah jeruk (Citrus $s p$ ) memiliki kandungan senyawa metabolit sekunder seperti saponin, flavonoid, dan tannin Adapun pengujian yang dilakukan yaitu kandungan senyawa alkaloid, flavonoid, saponin, tannin.

Hasil uji fitokimia ekstrak pektin dengan perekasi wagner dan meyer menunjukkan tidak adanya endapan coklat dan endapan putih kekuningan. Menurut Tiwari et al (2011), hal ini disebabkan karna alkaloid bersifat gugus basa yang mengandung nitrogen, sedangkan pektin bersifat asam sehinnga pada pektin tidak terdapat senyawa alkaloid.

Flavonoid adalah golongan pigmen organik yang tidak mengandung molekul nitrogen. Pigmen ini merupakan antraktan bagi serangga dan merupakan agen polinasi. Pigmen juga bermanfaat bagi manusia dan salah satu manfaat yang penting adalah sebagai antioksidan (Markham, 2011). 
Flavonoid mempunyai aktivitas antimikroba dengan mengganggu fungsi metabolisme melalui perusakan dinding sel dan mendenaturasi protein mikroba. Menurut Cowan (1999) senyawa flavon, flavonoid dan flavonol merupakan senyawa fenolik yang diketahui disintesis oleh tanaman sebagai respon terhadap infeksi mikroba. Mekanisme kerja sebagai antibakteri karena kemampuan untuk membentuk kompleks dengan protein ekstraseluler dan terlarut dengan dinding sel mikroba.

Berdasarkan hasil yang didapatkan ekstrak pektin menghasilkan busa, yang menandakan bahwa pektin mengandung saponin. Menurut Agoes (2012), Saponin adalah senyawa aktif yang kuat dan menimbulkan busa jika dikocok dalam air sehingga bersifat seperti sabun dan mempunyai kemampuan antibakterial. Saponin dapat meningkatkan permeabilitas membran sel bakteri sehingga dapat mengubah struktur dan fungsi membran. Saponin memiliki aktivitas antimikroba dengan menggangggu tegangan permukaan dinding sel. Saat tegangan permukaan terganggu zat antimikroba akan dengan mudah masuk kedalam sel dan akan mengganggu metabolisme hingga akhirnya terjadilah kematian sel bakteri (Karlina et al., 2013).

Berdasarkan hasil yang didapatkan, untuk pengujian tannin terbentuk warna hitam pekat yang menandakan bahwa dalam ekstrak pektin dari kulit buah jeruk bali (Citrus maxima) terkandung lebih banyak senyawa tanin. Tanin diketahui mempunyai beberapa khasiat yaitu sebagai astringen, antidiare, anti bakteri dan antioksidan (Desmiaty et al., 2008). Tanin mempunyai aktivitas antimikroba dengan targetnya adalah merusak dinding sel mikroba (Tiwari et al., 2011).

\section{Aktivitas Antimikroba}

Tetrasiklin merupakan antibiotik berspektrum luas yang dapat melawan pertumbuhan bakteri gram positif dan gram negatif. Mekanisme kerja tetrasiklin adalah menghalangi terikatnya RNA pada bagian spesifik dari ribosom, akibatnya sintesis protein mengalami hambatan (Widjajanti, 1988). Mekanisme kerja nistatin yaitu dengan mengadakan ikatan yang kompleks dengan ergosterol di membran sitoplasma jamur yang sensitif. Hal tersebut akan menyebabkan perubahan permeabilitas membran dengan membentuk pori-pori intra membran dan dengan demikian kehilangan intrasel penting senyawa, seperti ion dan molekul kecil, dan kemudian sel akan mengalami kematian (Brescansin, et al., 2013).

Hasil pengujian antimikroba pada tabel 4.3. menunjukkan bahwa ekstrak pektin dari kulit buah jeruk bali (Citrus maxima) memiliki aktivitas antibakteri dengan adanya peningkatan konsentrasi larutan ekstrak uji, namun tidak memiliki aktivitas antijamur dengan tidak terbentuknya zona hambat disekitar kertas cakram.

Berdasarkan tabel 4.3. Bakteri Escherichia coli, dapat dilihat bahwa kontrol negatif tidak berbeda nyata terhadap ekstrak pektin $0,5 \%$, berbeda nyata terhadap ekstrak pektin $0,75 \%$, dan sangat berbeda nyata terhadap ekstrak pektin $1 \%$ dan kontrol positif. Sedangkan terhadap bakteri Staphylococcus aureus menunjukkan bahwa kontrol negatif tidak berbeda nyata terhadap ekstrak pektin 0,5\%, dan sangat berbeda nyata terhadap ekstrak pektin 0,75\%, $1 \%$, dan kontrol positif. Hal ini sesuai dengan penelitian yang dilakukan Sari (2015), menunjukkan bahwa ekstrak pektin dari buah kulit jeruk memiki aktivitas antibakteri terhadap bakteri uji Staphylococcus aureus dan Escherichia coli.

Hasil pengujian aktivitas antijamur dari ekstak pektin kulit buah jeruk bali terhadap Candida albicans dapat dilihat bahwa kontrol negatif, ekstrak pektin 0,5\%, 0,75\%, dan 1\% tidak menunjukkan adanya aktivitas antijamur dengan tidak bertambahnya ukuran diamater dari kertas cakram sehingga hasil yang diperoleh tidak berbeda nyata. Hasil yang sangat berbeda nyata hanya diperoleh dari kontrol positif. Berdasarkan hasil penelitian Silvia (2018) menunjukkan pada konsentarsi 5\%, 10\%, tidak menunjukkan adanya aktivitas antijamur, namun pada konsentarsi $20 \%$ terdapat aktivitas antijamur, karna konsetrasi yang rendah.

Hasil negatif yang ditunjukan ekstrak pektin antijamur dapat disebabkan oleh konsentrasi ekstrak uji. Menurut Silvia (2018) konsentrasi ekstrak uji dapat mempengaruhi aktivitasnya 
sebagai antimikroba, konsentrasi yang tinggi dapat meningkatkan bahan aktif yang berfungsi sebagai antimikroba sehingga kemampuannya dalam menghambat pertumbuhan mikroba juga semakin besar.

\section{Kesimpulan}

Berdasarkan hasil penelitian, kesimpulan yang dapat diperoleh yaitu Faktor pH, suhu, dan waktu berpengaruh nyata terhadap rendemen pektin yang dihasilkan. Hasil rendemen pektin tertinggi diperoleh pada ekstraksi dengan $\mathrm{pH} \mathrm{2,5}$, suhu $60^{\circ} \mathrm{C}$, waktu 90 menit sebesar 27,8 \%. Bakteri Escherichia coli dan Staphylococcus aureus, menunjukkan bahwa ekstrak pektin dari kulit buah jeruk bali (Citrus maxima) memiki aktivitas antibakteri, sedangkan Candida albicans tidak menunjukkan adanya aktivitas antijamur.

\section{Referensi}

Asmara, anjar. (2017). Uji Fitokimia Senyawa metabolit Sekunder dalam Ekstrak Metanol Bunga Turi Merah (Sesbania grandiflora L. Pers). Jurnal Al-Kimia, 5 (1).

Agoes, G. (2012). Teknologi Bahan Alam . Penerbit ITB. Bandung.

Brescansin, E. G., Porthilo M., Pessine F. B. T. (2013). Physical and Chemical Analysis of Commercial Nystatin. Acta Scienriarum Health Sciences, 35 (2), 215-221.

Baehaqi, K. Y., Putriningsih, P. A .S., Suardana, Wayan. (2015). Isolasi danI dentifikasi Escherichia Coli. Jurnal Indonesia Medicus Veterinus, 3 (2).

Cahyanto, H A. (2017). Pektin Jeruk Bali (Citrus Maxima) dalam Formulasi Sirup Kering Buah Mengkudu. Jurnal Riset Teknologi Industri, 11 (1)

Cowan, M. M. (1999). Plant Products Products As Antimicrobial Agent. Clinica Microbiology Reviews. 564-582.

Djoepri, M R. (2006). Isolasi dan Identifikasi Mikroba Escherichia Coli (E. COLT) pada Makanan Sosis dan Nuget. Tema Teknis Nasional Tenaga Fungsional Pertanian, 265-266.

Djide, M. N., Sartini dan Syahruddin, K., (2007). Analisis Mikrobiologi Farmasi.LaboratoriumMikrobiologi dan Bioteknologi Farmasi, Fakultas MIPA, Universitas Hasanuddin. Makassar.

Fachruddin, Ir L. (1998). Membuat Aneka Selai. Kanisius. Bandung.

Fitria. (2013). Karakterisasi Pektin dari Limbah Kulit Pisang Kepok (Musa balbisiana). Skripsi. Jakarta. Fakultas Kedokteran dan Ilmu Kesehatan Program Studi Farmasi Jakarta.

Ganiswara, Sulistia. (1995). Farmakologi dan Terapi, EdisilV. Farmakologi Fakultas Kedokteran Universitas Indonesia. Jakarta.

Girma, Ermias., Worku, Mr T. (2016). Extraction and Characterization of Pectin From Selected Fruit Peel Waste. Samara University College of Engineering and Technology Department of Chemical. International Journal of Scientific and Research Publications, 6 (2) 
Herdigenarosa,Muren. (2013). Pembuatan Edible Coating dari Pektin Kulit Buah Jeruk Bali (Citrus maxima) dengan Variasi Sorbitol sebagai Plasticizer. Yogyakarta. Universitas Islam Negeri Sunan Kalijaga.

Hariyati, MN. (2006). Ekstraksi dan Karakterisasi Pektin dari Limbah Proses Pengolahan Jeruk Pontianak. Fakultas Teknologi Pertanian, Institut Pertanian Bogor: Bogor.

Ihwan et al. (2018). Uji Toksisitas Akut dan Letal Dose (LD50) Ekstrak etanol Daun Pepolo (Bischofia javanica Blume) pada Mencit Putih (Musmusculus). Natural Sciience: Jurnal of Science and Technology, 7 (1), 110-116.

Jawetz., Melnick, J L., Adelberg, E A. (2005). Mikrobiologi Kedokteran. Salemba Medika. Jakarta.

Kumalasari, Eka., Sulistyani, Nanik. 2011. Aktivitas Antifungi Ekstrak Etanol Batang Binahong (Anredera Cordifolia (Tenore) Steen.) Terhadap Candida Albicans Serta Skrining Fitokimia Antifungal Activity Of Ethanol. Jurnal Ilmiah Kefarmasia, 1 (2).

Karlina. C. Y., Muslimin I., Guntur T. (2013). Aktivitas Antibakteri Ekstrak Herba Krokot (Portulaca Oleracea L.) Terhadap Staphylococcus aureus dan Echerchia coli.

Krystiyani, Fanny. 2013. Pengaruh Ph, Suhu, dan Jenis Pelarut TerhadapKarakteristik Kimia Pektin "Albedo Jeruk Bali" (Citrus Maxima merr). Semarang. Unika.

Markham, K.R. (1982). Cara Mengidentifikasi Falvanoid. Alih Bahasa. Kosasih Padmawinata. ITB. Bandung.

Mercy N., Jemmy A., Vanda S K. (2013). Pengaruh Antibakteri Ekstrak Kulit Batang terhadap Bakteri $S$. Aureus secara Invitro. Jurusan Kimia FMIPA UNSRAT. Jurnal MIPA UNSRAT, 2 (2), 130.

Muhidin, Dudung. (2003). Agroindustri Papain dan Pektin. Penebar Swadaya. Jakarta.

Nurhayati., Laksona,P D., Sukatiningsih. (2013). Karakteristik Bubuk Tandan Pisang dari Empat Varietas Dan Potensi Pektinnya Sebagai Media Pertumbuhan Lactobacillus acidophilus. Jurnal Teknologi Pertanian.

Nurcahyani, Agustina dan Timous. (2011). Aktivitas Antioksidan dan Antibakteri Ekstrak Polar dan Nonpolar Biji Selasih (Ocimum sanctum L). Jurnal Teknologi dan Industri Pangan, 12 (1).

Puspitasari, L. N., Puspitasari, N., (2017). Prarencana Pabrik Pektin dari Kulit Kulit Jeruk Bali Kapasitas 264 ton pektin/tahun, Disertasi. Universitas Widya Mandala: Surabaya.

Prasetyowati., Sari, K P., Pesantri, Healty. (2009). Ekstraksi Pektin dari Kulit Jeruk. Jurnal Teknik Kimia,16 (4).

Perina, Irene., Satiruiani., Soetaredjo, F E., Hindarso, Herman. (2007). Ekstraksi Pektin Dari Berbagai Macam Kulit Jeruk. Jurnal Widya Teknik, 6 (1), 1-10

Pratiwi, ST. (2008). Mikrobiologi Farmasi, Erlangga. Jakarta. 
Efektivitas Ekstrak Pektin dari Kulit Buah Jeruk Bali (Citrus maxima) Sebagai Antimikroba

(hlm. 140-151)

Rahmi U, Yunazar M., \& Adlis S. (2013). Profil Fitokimia Metabolit Sekunder dan Uji Aktivitas Antioksidan Tanaman Jeruk Purut (Citrus histrix DC) dan Jeruk Bali (Citrus maxima) (Burm.f.) Merr). Jurnal Kimia Unand, 109-114.

Rahmat, H R. (2005). Jeruk Besar Potensi dan Prospeknya. Kanisius. Yogyakarta.

Rampengan, N H., (2013). Antibiotik Terapi Demam Tifoid Tanpa Komplikasi Pada Anak. Sari Pediatri, 14 (5).

Rahmawati, Ani., Putri, W D R. (2013). Karakteristik Ekstrak Kulit Jeruk Bali Menggunakan Metode Ekstraksi Ultrasonik (Kajian Perbandingan Lama Blansing Dan Ekstraksi). Jurnal Pangan dan Agroindustri, 1 (1), 26-35.

Rasak, Abdul., Djamal, Aziz., revilla, Gusti. 2013. Uji Daya Hambat Air Perasan Buah Jeruk Nipis (Citrus aurantifolia) Terhadap Pertumbuhan Bakteri Staphylococcus Aureus Secara In Vitro. Jurnal kesehatan Andalas, 2 (1).

Rika P,W., Sri L., Heru., Fajar T. (2014). Uji Aktivitas Antibakteri Ekstrak Etanol Daun Mangga Bacang (Mangifera foetida L) terhadap Staphylococcus aureus Secara Invitro. Naskah Publikasi Program Studi Pendidikan Dokter Fakultas Kedokteran Universitas Tanjung Pura. 7-13.

Rosalina, Yessy., Susanti, Laili., Karo, N Br. (2017). Kajian Ekstraksi Pektin Dari Limbah Jeruk Rimau Gerga Lebong (Jeruk Rgl) Dan Jeruk Kalamansi. Jurnal Agrointek, 11 (2).

Sari, Rafika., Mustari, F. Nour Aulia., Wahdaningsih, Sri. (2015). Aktivitas Antibakteri Ekstrak Pektin Kulit Jeruk Pontianak terhadap Staphylococcus aureus dan Escherichia coli. Jurnal Traditional Medicine Journal, 18 (2).

Sari, Y D., Djannah, S N., Nurani, L H., (2010). Uji Aktivitas Antibakteri Infusa Daun Sirsak (Annonamuricata L.) Secara In Vitro terhadap Staphylococcus aureus Atcc 25923 dan Escherichia coliAtcc 35218 serta Profil Kromatografi Lapis Tipisnya. Jurnal KesMas, 4 (3).

Susandarini, Ratna., Subandiyah, Siti., Rugayah., Daryono, B S., Nugroho, L H. (2013). Assessment of Taxonomic Affinity of Indonesian Pummelo (Citrus maxima (Burm.) Merr.) Based on Morphological Characters. Journal of Agricultural and Biological Sciences. 8 (3) 182-190.

Sriamonrnsak, Pornsak (2003). Chemistry of Pectin and Its Pharmaceutical Uses: Areview. International Journal, 3.

Silvia, devi. (2018). Uji Aktivitas Antifungi Ekstrak Kulit Buah Jeruk (Citrus sp) terhadap Jamur (Candida albicans). Skrispsi. Program Studi Biologi, Jurusan Sains, Fakultas Sains dan Teknologi, Universitas Islam Negeri Sunan Ampel.

Sulihono, Andreas., Tarihoran, Benyamin., Agustina, T E. (2012). Pengaruh Waktu, Temperatur, Dan Jenis Pelarut Terhadap Ekstraksi Pektin Dari Kulit Jeruk Bali (Citrus Maxima). Jurnal Teknik Kimia, 18 (4).

Sirait, M. (2007). Penuntun Kimia dalam Farmasi. Bandung: Institut Teknologi Bandung press. 
Septiani, Nanin. (2017). Analisis Senyawa Metabolit Sekunder dari Ekstrak Pektin dari kulit jeruk manis (Citrus sinensis) yang Berpotensi Sebagai Antioksidan. Makara Sains, 5 (1) 4852

Towle, G.A. \& O. Christensen. (1973). Pectin. In R.L Whistler (ed.) Industrial Gum. Academic Press, New York.

Tiwari, Kumar., Kaur Mandeep., Kaur Gupreet., Daur Harleem. (2011). Phytochemical Screening and Extraction: A Review. Internationale Pharma ceutica Sciencia, 1 (1).

Wang, X., Chen, Q., \& Lü, X., (2014). Pectin Extracted from Apple Pomace and Citrus Peel by Subcritical Water, Food Hydrocolloids. Journal of Food Science, (38) 129-137.

Wilianti, N P., Widjojo, Parno. (2008). Rasionalitas Penggunaan Antibiotik Pada Pasien Infeksi Saluran Kemih pada Bangsal Penyakit dalam Di RSUP Dr. Kariadi Semarang Tahun 2008. Jurnal Kesehatan, 2 (2).

\begin{tabular}{|l|l|}
\hline Nur Wana & $\begin{array}{l}\text { Prodi Biologi, Jurusan Biologi, Fakultas Matematika dan Ilmu } \\
\text { Pengetahuan alam, Univeristas Negeri Makassar } \\
\text { E-mail: nurwanawana82@yahoo.com }\end{array}$ \\
\hline Halifah Pagarra & $\begin{array}{l}\text { Ir, P.hD. Dosen Jurusan Biologi, Fakultas Matematika dan Ilmu } \\
\text { Pengetahuan alam, Univeristas Negeri Makassar } \\
\text { E-mail: } \underline{\text { fah rani@yahoo.co.id }}\end{array}$ \\
\hline
\end{tabular}

